\title{
Neoliberalism and Political Theologies of the Post-Secular: Historical, Political, and Methodological Considerations in a 20th and 21st Century Discourse
}

\author{
Kieryn E. Wurts
}

Citation: Wurts, Kieryn E. 2021.

Neoliberalism and Political

Theologies of the Post-Secular:

Historical, Political, and

Methodological Considerations in a 20th and 21st Century Discourse.

Religions 12: 680. https://doi.org/ $210.3390 /$ rel12090680

Academic Editor: Carl Raschke

Received: 7 July 2021

Accepted: 10 August 2021

Published: 26 August 2021

Publisher's Note: MDPI stays neutral with regard to jurisdictional claims in published maps and institutional affiliations.

Copyright: (C) 2021 by the author. Licensee MDPI, Basel, Switzerland. This article is an open access article distributed under the terms and conditions of the Creative Commons Attribution (CC BY) license (https:/ / creativecommons.org/licenses/by/ $4.0 /)$.
Department of Philosophy and Theory of Religion, University of Bonn, 53113 Bonn, Germany; s5kiwurt@uni-bonn.de or kierynwurts@yahoo.com; Tel.: +49-177-758-6891

\begin{abstract}
Carl Schmitt's controversial 1922 Political Theology: Four Chapters on the Concept of Sovereignty initiated a long-standing, lively, and oft misunderstood discourse at the intersections of religious studies, theology, and political theory. Political theology as a discourse has seen something of a revival in recent decades, which has raised genuine problems of interpretation. These include questions of what is at stake in political theology, how political theology can be applied to economic discourses, and how it can be understood in relation to secularity and post-secularity. This study takes Giorgio Agamben's The Kingdom and Glory as a conceptual bridge that helps to situate contemporary political theologies of neoliberalism historically and theoretically. A survey of four recent political theologies of neoliberalism yields a methodological reflection on the limits and potential of political theology as a discourse. A distinction is made between descriptive-genealogical political theologies and normative-prescriptive political theologies. The former is privileged in its philosophical potential, insofar as it reveals both the contingency and genuine variety of normative-prescriptive political theologies.
\end{abstract}

Keywords: political theology; neoliberalism; secularization thesis; post-secularity; Carl Schmitt; Giorgio Agamben; oikonomia; Carl Raschke; Philip Goodchild; Jürgen Habermas

\section{Introduction}

The past 15 years have brought renewed scholarly interest in political theology, resulting in many new published projects in this field. This diversity of contributions that constitute this renewal have, however, also given rise to a set of basic methodological questions. Put straightforwardly, it is not always abundantly clear what political theology is and what one is doing when engaging in this mode of analysis. The primary aim of this particular intervention is to address the methodological issues in political theology by engaging with an illustrative set of recent political theologies of neoliberalism. A political theology of neoliberalism presents two interpretive hurdles at the outset. The following can be understood as the frame questions which shall guide this paper:

(1) How should one interpret the proliferation of political theologies of economic phenomena? Do these projects simply indicate a distension of political theology as a discourse that, in trying to be all things to all people, has lost a sense of its interpretive or disciplinary boundaries? Or to pursue the question from another angle, where should the boundary between politics and economics be drawn, and where does political theology fit into this schema?

(2) How can one speak of theology in relation to neoliberalism? There is long-standing and lively discourse around neoliberalism as an economic phenomenon, as a political program, or simply as an era roughly beginning in the 1980s in the years preceding and following the end of the Cold War. There has been some discussion of the resurgence of religion as relevant to discussions around globalization and neoliberalism, with Samuel Huntington's Clash of Civilizations being the most well-known study of this kind. ${ }^{1}$ However, such discussions deal almost exclusively with religion 
or post-secularity as a sociological category. It would not occur to most mainstream political theorists or economists that theology might be a category relevant to discussions of neoliberalism. Insofar as neoliberalism is typically understood as a secular phenomenon, speaking of a political theology of neoliberalism remains a puzzling proposition for most who do not already consider themselves specialists in political theology itself.

The following account will begin with a short discussion of the secularization thesis and the challenge that political theology has posed to that thesis in the 20th century, especially through thinkers such as Eric Voegelin and Carl Schmitt. Schmitt continues to be understood as the founding figure of political theology due to his 1922 book by the same name. Some time will be devoted to situating Schmitt's argumentation in Political Theology: Four chapters on the concept of sovereignty as well as its historical significance. Schmitt by no means "invented" political theology, but his project did play an indispensable role to initiate and establish it as a mode of political inquiry in the 20th century. Giorgio Agamben is taken next as a paradigm-defining figure in political theology's development. The second volume in Agamben's Homo Sacer series, The Kingdom and the Glory: For a theological genealogy of economy and government (Agamben 2011), does a great deal of the theoretical work which enables us to distinguish between political theology and economic theology. Agamben offers a genealogy in which the Euro-Christian paradigm for governance is constituted by competing and mutually constitutive categories of sovereignty and economy, both of which are mediated through the administrative logic of oikonomia. A rather detailed discussion of Agamben's archaeology of oikonomia and its significance will yield to a survey of four contemporary political theologies of neoliberalism by Philip Goodchild, Joshua Ramey, Carl Raschke, and Roger K. Green. These two discussions taken together, the survey of Kingdom and the Glory compared with the discussion of the four political theologies of neoliberalism, should do much to resolve the first question of how political theologies of economic phenomena, or economic theologies, can be both historically and theoretically situated.

The final section will return to some methodological questions in political theology, especially—via a reading of Jürgen Habermas' arguments in Dialectic of Secularization-the question of how one can speak of a political theology of purportedly secular discourse. I posit political theology first and foremost as an interdisciplinary method tracing the manifold connections between political theory, economic theory, and religion. In problematizing the more utopian narratives of secularization, political theology calls into question the coherence of the claim that human culture ever has or ever could become post-metaphysical. Inquiries in political theology suggest that religious discourses need not necessarily recognize themselves as such, and indeed, this non-recognition of religious, theological, or metaphysical nature of political claims can have the paradoxical effect of intensifying their felt credulity. For this reason, genealogical-descriptive political theology is privileged over projects which can be described as normative-prescriptive political theology. While the latter mode of normative-prescriptive political theology certainly has merits, it is the former genealogical-prescriptive that has the most potential in making visible the elements of religiosity, intimations of cosmology, metaphysical orientations, and ideological positions are still very much at play in both contemporary political theory and practice.

\section{Origins and Horizons of Political Theology in the 20th Century}

\subsection{0th Century Narratives of Secularization and the Challenge of Political Theology}

In the political sciences, the secularization thesis posits that the processes of modernization and an increasingly rational and educated populace will result in a decline and eventual disappearance of religion and religiosity as societies develop. ${ }^{2}$ The post-WII move towards a more secularized understanding of the State was a culmination of a process began politically in the 1789 French Revolution. The philosophical roots of the secularization of the state can be traced even earlier than the French Revolution in the early-Modern political thought of Jean-Jacques Rosseau, Thomas Hobbes, Niccolò Machiavelli, Baruch Spinoza, and others. Indeed, anti-clericalism and the relativization of traditional religios- 
ity represents a major element of the Enlightenment project, both in its earlier and later instantiations.

Political theology serves as a counterargument to the secularization thesis, as it pertains particularly to political theory. In this view, the modern nation-State has not transcended the "pre-rational" religious concerns of the past centuries. Rather, as the German jurist Ernst Böckenförde observes, "the liberal, secularized state is nourished by presuppositions that it cannot itself guarantee" (Böckenförde 1991). Thinkers such as Böckenförde and Eric Voegelin argue that the theoretical foundations of the State cannot be fully separated from a set of religious, ethical, and metaphysical assumptions that inform it. In Europe, these ethical and metaphysical assumptions have their roots at least partially in the Christian theological tradition. Both thinkers tend to see modern theories of the nation-state to be in necessary continuity with preceding forms of government, whereas proponents of the secularization thesis hold that the modern nation-state is founded on a fundamental rejection of religiosity in the political sphere.

Jurgen Habermas is one thinker who responds to the Böckenförde thesis with a position that typifies some of the stances and assumptions of the secularization thesis. Habermas seeks a mediating position between defending the secularity of the state while simultaneously allowing for both religious expression and religious pluralism amongst its citizens, as well as for allowing meaningful participation in democratic society on the part of religious institutions ${ }^{3}$. For Habermas, the post-war nation-state represents a radical break from its predecessors insofar as it represents a civil community based solely on rational mutual necessity. This rational mutual interest is self-founding; it owes nothing to the traditions of political and religious authorities that precede it and requires no metaphysical or religious commitments as necessary for membership in the body politic. This approach allows for unprecedented pluralism in the public sphere, even as shared religious and metaphysical traditions are rejected as necessary for civic life. Habermas' position distinguishes itself from French-style Laicism in that he still allows for some function for religion and religious institutions in his conception of the public sphere. Religious actors can use religious language to translate the rational and humanistic values that undergird the secular nation-state into the cultural vernacular and, in this sense, can even be useful for political actors and government bodies. For Habermas, religion plays an optional functional role within civil society, but in no way may religion play a foundational role in the self-understanding of the state. Political theologians see the secular nation-state fundamentally differently. Rather than being seen as a fundamental break from the preceding state forms, secularity is understood genealogically as a continuation of a European cultural heritage. Political theology assumes a fundamental structural relation between the religious values of a society and its political structures. The development of one cannot be understood without recourse to the other.

A certain quotation from Carl Schmitt has become almost obligatory in any introduction to or discussion of political theology: "All significant concepts of the modern theory of the state are secularized theological concepts," and crucially he continues, "not only because of their historical development ... but also because of their systematic structure." (Schmitt 2015) Schmitt was originally referring to the analogy between Christian theology and the theory of state (Staatslehre), and Schmitt's analysis focuses primarily on the Sovereign state of exception, calling upon the traditional analogy between the Sovereign King and the monotheistic God. Jan Assmann famously inverted Schmitt's thesis, arguing that every theological concept is in fact an elevated and absolutized political concept, and applied his analysis with great import to the political and theological structures of pre-modern Egyptian and Hebraic societies ${ }^{4}$. Eric Voegelin argues similarly in his Neue Wissenschaft der Politik (The New Science of Politics) that

[Premodern Empires] portrayed themselves as representatives of a transcendent order, the order of the Cosmos .... Whether one turns towards the earliest Chinese sources in the Shu-ching, or the Egyptian, Babylonian, Assyrian, or Persian inscriptions, in each case the order of the Empire is interpreted as a 
representation of the cosmic order through the medium of human society. The Empire is a cosmic analogy, a microcosm as a mirror of the all-encompassing "macro-cosmos". Sovereignty becomes the task of bringing the social order into harmony with the cosmic order. ${ }^{5}$

Voegelin provides some insight into the important distinction between Habermas' radically immanent and self-foundational theory of state and premodern conceptions the political sphere as mirroring the broader cosmic order. Schmitt and Agamben do a great deal to bridge some of the distance between these two very different understanding of politics via their accounts of political theology with reference to European Christendom.

\subsection{Carl Schmitt: Inaugurator of Political Theology in an Authoritarian-Monothestic Register}

Carl Schmitt's 1922 publication of Political Theology marks the first explicit use of the term, around which the entire discourse later crystalized. Sovereignty, according to Schmitt, belongs ultimately to the political decision maker; the very act of decision making during the emergency or state of exception (Ausnahmezustand) constitutes the purest and most essential feature of sovereignty. According to Schmitt, the individual who exercises this decision-making capacity in the state of exception is, in the last instance, the Sovereign in the classical sense. The state of exception is the unprecedented or emergency situation in which all rules, laws, regulations, and norms of behavior are suspended. Sovereign legitimacy is inaugurated in the sovereign act, the sovereign decision, immanent unto itself, functions for Schmitt as a kind of "anointing of the King". This dynamic of sovereignty is necessarily at play in every political system; the sovereign decision during the state of exception is what Jacques Derrida will later term the "mystical foundation of authority" . The sovereign decision maker then quite literally "plays God" to his political system" . A new system of norms proceeds from the decision that is made in the state of exception; the decision made in the extra-judicial situation in turn generates the law. This is understood not only to be true in the finite case of juridical decisions made within a legal system, but this dynamic also takes on the force of a metaphysical state of affairs for Schmitt: hence political theology.

The sovereign in this understanding mirrors the creator God, who through an act of will speaks the Creation into being, ex nihilo. In a parallel sense, Schmitt's political decisionism hinges on a sovereign individual whose act of will generates a political order. This is for Schmitt unavoidable; it is the structure of the political. Schmitt advances his theory of authoritarian sovereign political decisionism as both (a) a mode of understanding the political that is more accurate than the liberal constitutional democracy's emphasis on rule of law and (b) the necessary auxiliary to a properly Christian monotheism. He certainly uses his political theory to advance both his anti-liberal political position as well as his particular arch-conservative understanding of Christianity. However, he also grants at a theoretical level that competing theories of the political, religious, and theological convictions produce alternative understandings of the nature of the political. Even according to Schmitt at this early stage, political theology need not be limited to Christendom, and alternative religious beliefs might produce their own distinctive political structures.

In the case of his 1922 study, Schmitt describes the modern constitutional state as being grounded in a Deistic theological understanding whereby the sovereign does not intercede in the political system, rather, the highest possible authority and mode of governance is a regular and predictable system of norms. He invokes Kant to polemicize against the de-personification of both the natural and the political order (Schmitt 2015). Kant's concept of autonomy involves the subject subsuming herself to a set of stable transcendental values. This understanding in turn influenced liberal modern political thinking; sovereign authority was relocated in the written law as opposed to being vested primarily in a sovereign individual. Just as Enlightenment, secular, and deistic thought all reject the possibility of the miracle, which can be understood as the state of exception on the metaphysical register, so the modern constitutional state rejects the possibility of the state of exception and the political relevance of the sovereign therein (Ibid., p. 43). This political understanding, with 
its analogous metaphysical undercurrents, is a political theology entirely at odds with Schmitt's political project. Schmitt seeks to re-invert this understanding; for him, it is the law which is subject to the sovereign, who for Schmitt must be the singular, sovereign personality-the sovereign authority for Schmitt must not only be vested in a singular authority, the decision itself serves as the very legitimation of sovereignty.

Schmitt was and remains a controversial and problematic figure. He was a stark critic of the Weimar Republic specifically and of the entire project of liberal constitutional democracy more generally. His 1919 work Political Romanticism (Die Politische Romantik) was his reaction both against the German Romantic tradition and the political optimism of the 19th century. Schmitt's response to what he terms the political romanticism of his time involved a fascination with authoritarian leadership as well as an emphasis on political decisionism. In Political Theology, he understood himself as a political theorist of the "counter-revolution", positioning himself in a tradition of Catholic traditionalist anti-liberal political theorists. Executive sovereignty established by way of the state of exception is the foundational act of state-making in his political thought. From this theoretical foundation, he endorses a highly traditionalist and authoritarian Catholicism as the moral, metaphysical, and organizational foundations of his philosophy of state. His preoccupation with the function of the sovereign decision as well as the status of the sovereign decision-maker led first to a fascination with Mussolini and Italian-style fascism in the early 1920s and culminated later in his support of the Nazi regime. Schmitt became a member of the NDSAP in May of 1933 in Berlin and was awarded a professorship (Lehrstuhl) at the Kaiser-Wilhelms Universität Berlin in the same year. Some characterized Schmitt as an opportunist, taking advantage of the opportunities for academic advancement left by the many scholars forced out of their positions during the 1933-34 Gleichschaltung. Indeed, Schmitt was even considered to be an opportunist by SS investigators in 1936, the year in which he lost many of his privileges within the German academy due to doubts about his political loyalties. Even as the sincerity of his Party loyalty was at times questioned, his political thought earned him the dubious designation as the leading jurist of the Third Reich $^{8}$.

In Schmitt, we witness one instantiation of a central methodological problem within political theology. The question is if a distinction stands to be made between political theology as a descriptive approach to political analysis as opposed to political theology as a normative or prescriptive theory of the political. Schmitt's Political Theology maintains no such distinction. Schmitt offers already in 1922 a neo-Hobbesean reaction to the post-WWI assertion of the secular liberal nation state. Schmitt can be understood in the tradition of Ockham's divine command theory, in which all manner of law, ethics, and morality hinges upon the will and decision of the divine personality. Such a divine command theory constitutes an uncompromising answer to Plato's Euthyphro dilemma. If the question is "Is the pious loved by the gods because it is pious or is it pious because it is loved by the gods?" ${ }^{\prime}$, Schmitt and all in this tradition answer in a resolute affirmation of the latter formulation-might makes right. Schmitt's political theology also reclaims something of those pre-modern conceptions of the political which understood the political sphere as a microcosm of ultimate cosmological truths. By way of this "mirrored" understanding of the political and the theological, this theological principle of might makes right holds true in Schmitt's philosophy of state.

While I would warn against any attempt at a political or moral rehabilitation of Schmitt, one can recognize the influence of this insight into a politics of "mirroring cosmos" as a crucial moment in the development of political theology. Of course, as demonstrated by thinkers such as Voegelin, this mirrored understanding of the cosmic and the political predates Schmitt-he did not invent it but rather re-articulated it in a way that had far reaching consequences for both politics and scholarship in the 20th century. Schmitt's Political Theology was indeed only an intimation in sketch form; he did not demonstrate his hypothesis so much as express a moment of insight. This moment of insight inspired further scholarship amongst later theorists. Schmitt's Political Theology is a work that 
inaugurated a significant line of inquiry in 20th century political theory but should not necessarily be considered a high point of said discipline.

\section{Giorgio Agamben's Political Theology of Government and Oikonomia}

Giorgio Agamben's interventions in his Homo Sacer series have proven decisive in the development of political theology. Unlike Schmitt's Political Theology, Agamben's Kingdom and the Glory is not a prescriptive theory but rather an archaeology of the theological and political paradigms which have shaped the way political power has been understood and deployed by Euro-Christian actors. ${ }^{10}$ For Agamben, the field of sovereignty and the field of economics are coded in the Greek-Christian logic of oikonomia. Okonomia, which can also be translated as 'administration', simultaneously differentiates between sovereignty and economy while also uniting them in a singular structure of governance. Agamben holds that an understanding of governance in both its sovereign and economic forms necessitate a recourse to the history of Christian theology:

One of the theses that we shall try to demonstrate is that two broadly speaking political paradigms, antinomical but functionally related to one another, derive from Christian theology: political theology, which founds the transcendence of sovereign power on the single God, and economic theology, which replaces this transcendence with the idea of oikonomia, conceived as an immanent ordering-domestic and not political in a strict sense-of both divine and human life. Political philosophy and the modern theory of sovereignty derive from the first paradigm; modern biopolitics up to the current triumph of economy and government over every other aspect of social life derive from the second paradigm. (Agamben 2011)

The Kingdom and the Glory, published first in 2007 and translated into English in 2011, represents a pivotal moment in the development of the discourse of political theology. In large part due to Schmitt's influence, the question of political sovereignty has been the most typical focus of inquiries in political theology, especially in the 20th century ${ }^{11}$. However studies at the intersection of political theology and neoliberalism began appearing around the early-aughts and have developed into a vibrant discourse focused specifically on the intersections of economic phenomena and theological paradigms ${ }^{12}$. The Kingdom and the Glory lays a framework for thinking about these connections-between politics, economics, and theology, broadly speaking - which provides a necessary background for these more recent discourses in economic theology. Indeed, recourse to some of the finer points of Agamben's argument in the coming section will help to clarify the connections between theology and governance by way of the logic of oikonomia as they have developed in the history of ideas. The systematic and historical nature of this argument serves not only to contextualize recent projects in economic theology. It also serves as something of a defense of the relevance of political theology as method ${ }^{13}$. Critics of political theology as an approach often question the rigor of the discourse, misunderstanding it as rather niche and vague discussions at the intersections of politics and religion. Calling on some of the finer points of this argument demonstrates that political theology as discourse goes much deeper than simple discussions about religion and politics.

\subsection{Oikonomia in Ancient Greek Usage}

Essential to Agamben's archaeology is his understanding of the signature-a concept or expression that codes itself over various contexts and epochs. The meaning of the term or concept which leaves a signature is flexible but the significance the term accumulates in one epoch is transferred to the next epoch by virtue of its use in both. In this way, distinctive epistemes code and influence the development of one another. The Kingdom and the Glory begins with a word study of oikonomia, demonstrating how the concept left its signature across the development of the western political and theological tradition and begins with the ancient Greek and Aristotelian usages in which oikonomia designates the 
"administration of the house." Aristotle, in his Politics, opposes the techne oikonomike to politics proper by distinguishing between the governing figures: the politician and the king are to the polis as the oikonomos and the despotes are to the family and household. The antique household was more visibly a wealth-generating enterprise than the contemporary single-family household. The oikonomos or despotes, the citizen, father, master, or the "head of the household" could all be names given to the central male-authority that led such a household/enterprise. His authority over the members of his household was absoluteslaves, livestock, wives, and children were all subject to his absolute authority. Ideally, authority was not practiced by virtue of what we would today term despotism - the purely self-referential exercise of authority. Rather the authority of the head of household was subject to the logic of the oikonomia, of "home economics". Each member of the antique household served a particular role, as an essential piece of a wealth producing unity-slaves provided agricultural and household labor, livestock nutrition to sustain the household, wives produced children that could serve as both a source of labor and as inheritors of the estate. This structure of household hierarchy proves to have enormous staying power in the history of European political and theological thought, as we shall soon see in greater detail. ${ }^{14}$ The principle of the oikonomia leaves its signature on the concept of the political, as the figure of the oikonoimos leaves its signature on the western conceptions of rightful political leadership.

The head of household served as administrator, proprietor, and also occupied a place in the polis. The logic of the polis bore some similarities to that of the household-it also functioned as a sort of enterprise; merchants, politicians, and soldiers all served a function in the maintenance and defense of the collective. The innovation of Athenian democracy was then that these male citizens were not reduced exclusively to their function of maintaining the polis, and they were afforded a certain degree of autonomy in their status as Greek citizens, even as this individual autonomy was limited by broader interests. Such a status was denied slaves and women, whose political status was roughly equivalent to that of the livestock: they were understood, ultimately, as functionaries of the economic machine that was the household. Already we begin to observe the bipolarity of governance so important to Agamben's project: the two realms of politics and economy operate in the Greek context as distinctive but complementary paradigms bearing the relationship of microcosm (household) and macrocosm (polis). The concerns of the polis are expanded, as governance and rule involve the management of multiple households subsumed by the larger political unity generate new dynamics and an expanded logic of administration which we might term the realm of the properly political: the sphere in which the expanded autonomy of citizens (as opposed to the non-autonomy of members of the household) creates a realm wherein power is contested. Where power is contested, politics is possible. The antique household is then not a political sphere in the proper sense, as the head of the household maintains, at least in the official and legal senses, uncontested authority and his decision making is mediated by an economic logic of necessity. This tension between conceptualizing the government as either a democratic polis or an autocratic oikonomia is one of the animating tensions in the history of political thought.

\subsection{Oikonomia in Early Christian Trinitarian Theology}

The word oikonomia was later applied in a quite different context, namely that of Christian Trinitarian theology. In this new theological field, Agamben argues that the meanings and usages of oikonomia by ancient Greek thinkers leave their signatures upon the later and seemingly thematically distant Christian theological usages. In his word study of the Pauline usage of oikonomia in the first century, Agamben concludes that Paul does not conceptualize the Christian ekklesia as a political entity, but rather as a household, an oikonomia, and thus utilizes a more economic paradigm in his epistles to the early churches, using terms such as doulos (slave), hyperetes, diakonos (servant), and oikonomos to refer to himself and the members of the messianic community (Agamben 2011). Agamben notes that kind of rhetoric is not an exclusively Pauline innovation but rather that it reflects 
the first century Zeitgeist, whereby the Aristotelian distinction between the demos and the oikonomia was rejected and the political sphere was conceptualized increasingly as simply an oikonomia writ large. The Early Church is typically understood in economic and administrative terms arranged according to a unified will or a singular telos. One of Agamben's primary methodological principles is that, often, in order to recognize the organizing principle of one discipline - in this case, political theory-it is necessary to seek their antecedents in a seemingly unrelated field. Such is the archaeological method that undergirds Agamben's political theology. In this spirit, we might draw attention to a passage from the First Letter to the Corinthians, which expresses what are fundamentally issues of administration through an extended metaphor of the body. While Agamben does draw attention to some references to the economic metaphor of the body some of the Church Fathers living between the first and third centuries, for example, in the Address of Tatian to the Greeks (Ibid., p. 54), he seems to miss the origin of the metaphor of the body for the Christian ekklesia in the Letters of Paul:

For just as the body is one and has many members, and all the members of the body, through many, are one body, so it is with Christ. For in the one Spirit we were all baptized into one body_-Jews or Greeks, slave or free-and we were all made to drink of one Spirit.

Indeed, the body does not consist of one member but of many. If the foot would say, "Because I am not an eye, I do not belong to the body," that would not make it any less a part of the body. If the whole body were an eye, where would the hearing be? If the whole body were hearing, where would the sense of smell be? But as it is, God arranged the members in the body, each one of them, as he chose. If all were a single member, where would the body be? As it is, there are many members but one body. The eye cannot say to the hand, "I have no need of you," nor again the head to the feet, "I have no need of you." On the contrary, the members of the body that seem to be weaker are indispensable, and those members of the body that we think less honorable we clothe with greater honor ... But God has so arranged the body, giving the greater honor to the inferior member, that there may be no dissension within the body, but the members may have the same care for one another. If one member suffers, all suffer together with it; if one member is honored, all rejoice together with it.

Now you are the body of Christ and individually members of it. And God has appointed in the church first apostles, second prophets, third teachers; then deeds of power, then gifts of healing, forms of assistance, forms of leadership, various kinds of tongues. ${ }^{15}$

This passage offers an extraordinary example of the administrative paradigm both naturalized and theologized through the metaphor of the body. The political, theological, and ontological registers blend into one another such that one cannot be certain which is originary. This is an example political theology at its most powerful-a seamless ontologizing of political concepts, or perhaps a seamless politicizing of a particular ontology. Paul includes an ethical dimension to his vision of the church as body. Through the metaphor of the body the community takes part in a shared life with a singular shared purpose, whereby significance is attributed to each member. There is an attempt to simultaneously reify and relativize questions of status and hierarchy. This and other writings complicate an ethically dualistic account of the paradigms of the demos and oikonomia. One can certainly identify autocratic tendencies within the oikonomia, but democracy, especially in its antique form, does not constitute its opposite. Ours is not a case of two competing paradigms, one being morally reprehensible and the other being the utopian ideal. Rather in most democratic political systems from ancient Athens forward, we see the logic of the oikonomia integrated into the logic of the demos; Agamben characterizes them as the two pillars that gird the realm of the political. We will next explore how the signature of the oikonomia coded itself onto later developments in Christian theology. 


\subsection{Economy of the Mystery to Mystery of the Economy}

In the third chapter of the Kingdom and the Glory, Agamben cues the reader to the development of the Pauline syntagma "economy of the mystery" and its development into the "mystery of the economy" through the writings of the Church Fathers. As previously stated, Paul understands himself as a kind of oikonoimos ${ }^{16}$ : an administrator tasked by God to share the Good News of His salvific plan for humanity. In the Pauline understanding of the economy of the mystery, God's will is a secret and transcendent mysterium which is gradually revealed and realized in history. Agamben traces a subtle development signaled in the reorientation of this syntagma. The "economy of the mystery" is transformed in the later writings of Hippolytus and Tertullian to the "mystery of the economy" (oikonomias sacramentum) and thereby introduces a strain of political obscurantism in the reversal, which is also to be found in other thinkers such as Origen and Clement of Alexandria. ${ }^{17}$ In this rendering, just as the inner workings of the Trinity remain essentially mysterious, so too are the workings of the Church and political powers rendered largely inscrutable. In contrast to the Pauline economy of the mystery, in which God reveals a mysterious plan of salvation throughout history, in the mystery of the economy, the economy of the ecclesial institutions is absolutized. The Church's claim to legitimacy rests on its self-understanding as the mediator of God's will on Earth. The providence of the Christian God is expressed in the fact of ecclesial authority, not primarily in the progressive realization of a redemptive plan for the Creation. The redemption is the mystery is the authority. Indispensable to this development, according to Agamben, is the logic of the oikonomia. This administrative paradigm, originally developed in the very earthly realm of household politics, is abstracted and applied to the internal workings of the Triune Godhead. Agamben argues that after being "theologized" in the Truine Godhead, the administrative logic of oikonomia was again "re-immanetized" and applied to the structures of earthly ecclesial and political powers. This becomes particularly visible in the Middle Ages. It is administrative logic that runs through the premiere theological thinking of Late Antiquity and the Middle Ages and is mirrored in the political theory of the same epochs. It is this tradition that Schmitt called upon in the early 20th century in naming the intertwining structures of European political and juridical thought.

\subsection{Oikonomia of Governance through the Roi Mehaignié}

To articulate the relation between the sovereign authority and the government, in both the political and theological spheres, Agamben invokes the Arthurian myth of the roi mehaignié-the mutilated king. As the myth goes, this King is wounded between the thighs and as a result is rendered unable to reign, or even leave his room. He also loses his capacity to hunt, and his falconers, archers, and hunters must continue with their activities in his absence. ${ }^{18}$ According to the myth, the mutilated king can only be healed when his wound is smeared with the blood of Christ using the spear which was used to mutilate Christ on the cross. Agamben interprets the story as "a genuinely political mythologem, which can be read, without forcing things, as the paradigm of a divided and impotent sovereignty. Even if he does not lose any of his legitimacy and sacredness, the king has in fact for some reason been separated from his powers and activities, and reduced to impotence," (Agamben 2011). Where Schmitt emphasizes the decision in the state of exception as the sovereign activity par excellence, Agamben draws our attention to the notable inactivity of the sovereign in the normal state affairs and introduces the paradigm of the sovereign who reigns but does not govern as not merely an odd paradox, but inherent to the structure of western political thought.

Agamben argues that similar to the figure of the King or sovereign stands in analogic symbolic relationship with the monotheistic $\mathrm{God}^{19}$, the figure of the angel, as developed throughout Christian history, can be understood as the deification and mythologization of the King's minister, advisor, or official. Agamben invokes De gubernatio mundi of Thomas Aquinas as well as Pseudo-Dionysius' Celestial Hierarchies to demonstrate the seriousness with which angelic hierarchies were discussed during the Middle Ages. For Thomas, this 
panoply of angelic ministers can stand only in a perfectly hierarchical relationship to one another, as if emanating from a First Cause. Indeed, Aquinas and the Pseudo-Dionysius both owe much of their Angelology to the Aristotelian First Cause and Neoplatonic metaphysics of emanation. These angelologies are simultaneously theological and political articulations. We might invoke here the Zizekian parallax view in our understanding of political theology - the two disciplinary poles constitute a discourse similar to optics, whereby the two distinct images constitute the third image, while each retaining their distinct status as separate images. ${ }^{20}$ On the theological register, we find an attempt at the resolution of that stubborn aporia inherent to monotheism: how can a completely ineffable, radically singular principle whose perfection is defined by its utter transcendence possibly have any connection to the created order or the world as such? Pseudo-Dionysius establishes this connection through the oikonomia of the angelic hierarchy, the structure of which was so thoroughly influenced by the emanationist principles of Proclus and Plotinus. ${ }^{21}$ In the Angelic hierarchies, we witness yet again an attempt to link the general to the particular via an administrative logic.

In his Mystical Theology, the Pseudo-Dionysius compares God to "a darkness beyond all light". ${ }^{22}$ This negative theology of a God beyond all attributes leaves us with an intimation of the aporetic relationship between being and nothingness. Agamben establishes in his second Chapter of The Kingdom and the Glory the historical innovation in Christian theology, whereby the being of God is severed from the activity of God through a logic of administrative mediation-sometimes achieved via a Trinitarian theology and at other times through an angelic cosmology. In the Pseudo-Dionysian Angelology, we see the unheimlich intimation of God as an unknowable placeholder, and the Angelic Hierarchies as an organization around an emptiness.

This theological aporia is translated as political aporia via the roi mehaignié, the king who reigns but does not govern. The essential impotence of the King has a parallel structure to the metaphysical alterity of God. Structurally, the problem lies in the attempt to organize the political and social world under a single principle. Equally, there are practical limitations for a single person to truly govern a realm or territory. In the figure of the Emperor, the King, the Lord, or the Dictator, we see an attempt to subsume the political world under the decisionistic governance of a single person, which is practically impossible in every instance. In this sense, every King is impotent, not just the unfortunate roi mehaignie. The compensation for this necessary impotence is then ministers, bureaucrats, and officials who enact day-to-day governance. This is the dynamic behind the "King who reigns but does not govern." Here, we see the political and symbolic significance of the analogy between political officials enacting the will of the Sovereign and the angels enacting the power of God.

In the figure of the King or Sovereign, we see the symbolic attempt to personify the singular principle that organizes community and political life in the figurehead. Some of these assumptions are reflected even in contemporary, secular governance. The head of state, whether it be the King, President, Prime Minister, or even Dictator, symbolically articulates the singular organizing principle of the body politic and enjoys a level of honor, ceremony, and public attention wholly distinct from his/her actual acts of day-to-day governance. Agamben argues that rituals of acclamation are essential to the consolidation and maintenance of political power, and he locates the contemporary rituals of acclamation in apparatuses of mass media, understanding them as a historical continuation of the previously visibly Christian acclamations of Sovereign power in Europe. We find here significant structural parallels between this trifold oikonomia of political governance and Trinitarian Christian theology.

\subsection{Kingdom and the Glory's Relevance for Later Developments in Economic and Political Theology}

Agamben provides an understanding of how political theology emerges, of how understandings of the cosmic and moral order evolve by way of the signature-in which distinct discourses from wildly differing epochs almost unconsciously code one another. 
Oikonomia serves as a prime example of this process, in which a concept of something akin to "household economics" with origins Aristotelian and ancient Greek political theory later developed into a Christian theological explanation of the interplay between the Triune Godhead, which later transforms into a veritable cosmology, in which oikonomia comes to designate something of the interplay between God and his angelic intermediaries in High Middle Ages. This cosmology or Angelology in turn influences theories of governance the Middle Ages, early-Modern, and Modern eras and through it he articulates a trifold theory of governance as it has functioned in European history - an oikonomia between three poles of political power: the Sovereign, the administrators of sovereign authority, and the public. This cosmology continues and is particularly potent in an aestheticized form in Baroque art and culture.. This hierarchical, monarchical, and monotheistic cosmology of administration indeed unites the political forms of the High Middle Ages and early Modernity.

Through Agamben's genealogy of the signature, these developments all seem quite arbitrary but precisely therein lies the subtlety of Agamben's political theology; these usages of oikonomia would not have been seen as arbitrary at all in their original context but rather would have been understood to represent the natural or true order of things. The most potent and influential theology, religion, or ideology is one that does not recognize itself as such. Political theology in the 20th century has developed into the discipline of drawing the connections between articulations of theological or religious truth and seemingly unrelated expressions of political necessity or imperative. A 20th century debate between Carl Schmitt and theologian Erik Peterson regarding political theology, the politics of acclamation and Peterson's Monotheism as a Political Problem serves as something of a "frame story" for Kingdom and the Glory. Agamben's is a political theology primarily of Late Antiquity and the High Middle Ages. It is only implied through the genealogical method and through the Schmitt/Peterson "frame story" that his political theology is implied to be of contemporary relevance. The exact nature of this relevance is left to the reader to infer.

Agamben's work on the genealogy of oikonomia has drawn some strong criticism from thinkers such as Dotan Lesham. Indeed, Lesham understands his work, The Origins of Neoliberalism: Modeling the Economy from Jesus to Foucault, as a refutation of Agamben that ultimately renders Agamben's genealogy "meaningless" (Lesham 2016). Lesham offers significant new historical and philological insight into the development of oikonomia which problematizes some of Agamben's conclusions, especially calling into question many basic assumptions that would essentialize or seek to oversimplify the relationship between Christian theology and neoliberal economic thought. Still, as rich as Lesham's insights and contributions may be and as much as his Origins of Neoliberalism represents genuine progress in the scholarship, warranting its own careful handling regarding the implications for economic theology, to argue that it completely forecloses upon Agamben's project in Kingdom and the Glory would constitute an exaggeration or oversimplification. Agamben's formulation of the bipartite- that is, at once competing and mutually constitutive categories of economy and government-not only remains a historically and philosophically compelling insight in its own right, but it is also a contribution which has motivated and enlivened an entire subsequent discourse around economic theology. Agamben's theoretical distinction between political theology and economic theology does much to make something like a political theology of neoliberalism intelligible as a line of theoretical inquiry.

Recently, there have been an evocative series of projects dedicated to a political theology of neoliberalism. The following section will investigate four recent political theologies of neoliberalism from Philip Goodchild, Joshua Ramey, Carl Raschke, and Roger K. Green as rich and varied attempts to account for the deep frames which influence the neoliberal economic order. The engagement with these works should be understood as illustrative rather than encyclopedic. There are indeed multiple other relevant and recent works of political theology which could have been included in a more encyclopedic account. ${ }^{23}$ The four works in question were, however, not merely chosen at random but represent approaches which help to provide answers to the two framing questions of this study, namely, (1) how political theology and economic theology can be understood 
as complementary modes of inquiry especially when understood within the tradition of Agamben's Kingdom and the Glory and (2) how political theology can provide insight into purportedly secular discourses. It is also relevant that each of these works employ a descriptive-genealogical approach to political theology, the merits of which will later be more fully discussed.

Goodchild's Theology of Money and Raschke's Political Theology of Neoliberalism constitute rich and somewhat standard-bearing interventions into economic and political theology of neoliberalism, while Ramey's Politics of Divination and Green's Political Theology of Psychedelic Aesthetics represent promising innovations in approaches to political theology. Politics of Divination is a work of economic theology not overly concerned with Christianity but rather focusing on divination, which is conventionally considered a "pagan" religious expression. Green's intervention intimates some of the illuminating potential the fields aesthetics and literary theory have for political theology. Each of these projects employ a critical approach to a common story told about the neoliberal economic environment, particularly associated with the neo-classical Chicago School of Economics, which holds that the neoliberal order is a product of purely rational economic imperatives, an expression of Leibniz" "best of all possible worlds" to which, to follow Margaret Thatcher, "there is no alternative". Instead, these thinkers employ the analytic methods of political theology in order to bring to the foreground the metaphysical assumptions, ritual practices, and positively religious orientations which undergird and constitute the neoliberal world order. Goodchild and Ramey's works can be understood heuristically through Agamben's typology as excurses in economic theology, while Raschke's and Green's projects can be classified as political theologies, insofar as they concern themselves with questions more typically understood as political rather than economic concerns.

\section{21st Century Political Theologies of Neoliberalism}

The fall of the Soviet Union in the early 1990s was a watershed moment which culminated in a set of political and economic conditions that we now designate with the moniker neoliberalism. Neoliberalism, however, is also deeply figured by this undergirding tension between paradigms of politics and paradigms of economics; neoliberal ideology involves the ultimate supplanting of politics as such in favor of a pure economics. For the convinced neoliberal, politics itself is utterly passé, the sovereign is he who has amassed the most capital. All conflict can and should be arbitrated by the pure logic of the market. Indeed, Adam's Smith invisible hand of the market renders the scales of justice utterly redundant. The utopian future of the convinced neoliberal is that in which all politics is subsumed into a pure economics. Herein lies the significance of Francis Fukyama's end of history; the Fall of the Berlin Wall is taken as an eschatological sign of the coming capitalist paradise.

Neoliberalism can designate an ideology, typified by the doctrines of the Chicago School of Economics, but it can also be used as a moniker to describe an era spanning 1989 to the present day. The subsumption of politics into an economics of pure rationality is of course, only a pious story. Political decisions, sovereign decisions, and distributions of power are still routinely enacted and enforced in the neoliberal era. Despite the tension between the two categories, one can still speak of both of neoliberal politics and neoliberal economics. Some of the defining economic features consistent with the neoliberal era include (1) the implementation of austerity mechanisms combined with a consistent and escalating dismantling of the social state; (2) the advancement of free-trade policies for goods and services with parallel restrictions on movements of persons and labor; (3) predatory debt and lending practices, which is a particularly extreme practice in the US context; and (4) the advent of ever more precarious and ill-paid work across the labor market through mechanisms of de-regulation-both on the level of internal policy of States and external politics of colonization of cheaper and underregulated labor markets of weaker states and regions. Each of these features cannot be understood as a logic of pure economics that supplants classical paradigms of the political but rather as a series 
of political programs and decisions advanced to consolidate the power and wealth of the world's wealthiest classes.

\subsection{Goodchild's and Ramey's Economic Theologies}

The authors of these most recent political theologies of neoliberalism all share the recognition that classical economics is an insufficient paradigm for theorizing economy, as such. In his 2009 Theology of Money, Philip Goodchild contends that "The history of Christian reflection on money is of limited service [to my inquiry] insofar as it concentrates on subjective attitudes toward wealth; the history of economic science is of limited service insofar as it concentrates on an objective science of money as functional instrument" (Goodchild 2009). Money begs a philosophical account insofar as is purported as an instrument a system for universal evaluation, itself having a dual nature, which paradoxically both embraces and resists determinate valuation (Ibid., p. 16.). It begs a historical and a phenomenological account, what Goodchild terms an ecology of money as well as a politics of money, or an account of the power relations it engenders. Finally, Goodchild elaborates a theology of money, or an account of the system of belief and devotion enacted through systems of credit and debit (Ibid., p. 18).

For Goodchild, the Christian God, or perhaps more accurately, the God of the philosophers and object of theologia naturalis, shares several important attributes with money. In a similar vein, theology and economics converge on an important point: both discourses purport to provide an account or theory of value. Economics is understood as a system of assigning and manipulating value and values through the technology of money. The central question of theology, following Goodchild, is what is the source of the value of values? The definition of money in classical economics is provided as at once an instrument of exchange, a measure of value, and a store of value (Ibid., p. 207). The classical definition of God is provided in Thomas Aquinas' formulation of God as the True, the Good, and the Life, whereby "all beings may be judged according to their truth, goodness, and life, but God alone is at once both ultimate criterion and eminent instance." (Ibid., p. 205).

There is a certain analogia entis between God and money, insofar as both are posited to be the same for being and the same for thought, to solve the perennial problems of metaphysics in offering a solution to the problem of the source and mediation of all value. The analogy continues in that both God and money fail to make entirely good on their promises as mediators and solutions to the problems of metaphysics, epistemology, and ethics. Money is purported to be a stable measure, store, and mediator of value. It is purported to be the same thing for being and thinking, more pure than language insofar as the sign of value and the value that it signifies converge, "it says what it says and says what it is." (Ibid., p. 208) However, Goodchild lays bare the manifold contradictions inherent in money as a technology, the injustices which financialized logic necessitates by its own system of accounting, and the fundamental incompatibility between financialized capitalism operating on a logic of infinitude and the finite world of persons, time, and resources which it claims to valuate in an absolute sense. The value of money cannot, in the last instance, be evaluated. Money and God share this quality. God, as transcendent simple Unity and ultimate value of Goodness, Truth, and Life cannot seem to make good on the promise of providing a stable, absolute, and unchanging verification of values within the immanent frame of the lifeworld. The implications of these incompatibilities of both money and God with the Creation are too numerous to recount here. It must suffice to say that Theology of Money can be understood as an economic theology in the fullest sense, insofar as it offers an account of the analogies, resonances, and points of convergence between theological or metaphysical issues and the ordering of our economic worlds.

Whereas Goodchild reads financialized capitalism and the neoliberal world order which it produced as ultimately a product of the Christian tradition, Joshua Ramey offers an alternative political theology of money in his 2016 Politics of Divination. The influence of Goodchild's method and insight can be felt in that both works focus specifically on an economic theology of neoliberal economic theory and practice, contemporary financial 
instruments, and Wall Street speculation, and both works are inspired by the dark and far-reaching consequences of the 2008 financial crisis. Ramey, however, ultimately claims that neoliberal financialization reflects a divinatory, oracular, and positively pagan religious sensibility. Ramey defines the market as both a site constituted by uncertainty while simultaneously being implicitly understood within economic discourse $a$ la the Chicago and Vienna Schools as a form of cosmic order which reward proper piety, civic virtues, and allegiance to the proper gods. However, unlike in a traditional Christian cosmology, luck is a stronger principle than justice. Chaos or random fortune and misfortune are important features of the cosmos that can take precedence over principles of right and wrong. However, even as the neoliberal economic order is purportedly ruled by a principle of chance, Ramey also recognizes disavowed practices of governmentality, whereby markets are manipulated to exclude, impoverish, and marginalize unwanted actors. In this neoliberal cosmology or "secular providentialism", economists and financial experts, speculators and entrepreneurs play the role of "master diviners ... seers, oracles, and keepers of the keys of non-knowledge" (Ramey 2016). If one would want to find great shows of devotion, respect, obedience, or praise in neoliberal culture, Ramey suggests to simply follow the money-the flow of capital. Ultimately, this neoliberal religiosity, this worship of financial flows, exhibits "an uncanny and generic resonance between specifically post-Protestant secular providentialism on the one hand, and archaic, premodern and even animist notions of irreducibly local powers [on the other]"(Ibid., p. 13). Ramey's understanding that neoliberal piety does not exclusively exhibit Christian religious features but also attributes of "pagan" religiosity does not put his work fundamentally at odds with Goodchild's or other accounts. More broadly, I would argue that political theology should be understood to have broad import in religious studies, that it would be a mistake to limit political theology as a discourse to the realm of what is traditionally understood as "Christian". More elaboration of this position will have to, however, be briefly postponed.

\subsection{Raschke's and Green's Political Theologies}

While Goodchild and Ramey are primarily focused on theological readings of the economic mechanisms endemic to neoliberalism, two recent works from Carl Raschke and from Roger Green are political theologies which can be read on the other side of Agamben's conceptual Economy/Governance binary-as accounts of the political aspects of the neoliberal world order. Carl Raschke's 2019 (Raschke 2019) Neoliberalism and Political Theology: From Kant to Identity Politics makes use of political theorist Wendy Brown's accounts of progressive neoliberalism to expand a political theology of the "cosmopolitan ethos". Raschke engages a genealogy of neoliberalism, demonstrating how earlier state and economic forms are implicated in the contemporary economic and political world order. He provides a counterpoint to the narrative of the post-WWII liberal nation-state as a radical departure from the Empires, colonial structures, and religious understandings that preceded it. Three significant predecessors include:

(1) The legacy of European colonialism, especially regarding the brutal exploitation of both persons and commodities, which was energized and justified through the ideology of the European "civilizing mission", lending a veneer of moral goodness to the self-understanding of the colonizers. This ideology of a "civilizing mission" portrayed European colonizers as undertaking significant personal risk in order to reach the indigenous peoples in Asia, Africa, and South America with their supposedly superior moral, educational, and technological cultures. Raschke emphasizes this narrative and its parallels to the moralistic stories told today which serve to justify and distract from some of the most brutal forms of contemporary neo-colonial exploitation.

(2) Raschke understands 19th century Prussian innovations in 'state socialism' (Staatssozialismus) as a predecessor to neoliberal techniques of technocratic governmentality. Crucial to this story was the introduction of universal education by Frederick the Great. Prussia's paradigmatic development of universal primary, secondary, and university education throughout the long 19th century nurtured an educated class of citizenry loyal to the 
abstract interests of the State. Such a system was protected and guaranteed by a parallel system of militarization and economic protectionism. In the mechanisms of the Prussian Empire, Raschke identifies innovations in governmentality which Foucault would term "biopolitical", which also inform techniques of governmentality employed in today's neoliberal "knowledge society".

(3) The legacy of the Imperium Romanum-As in ancient Rome, the neoliberal ideal is of an all-encompassing cosmopolitanism, in which all religious, ethnic, geographic, and ideological difference can be integrated into a streamlined and profitable Empire. However, this integration of various people groups across vast territorial expanses was implemented primarily for the enrichment of a small political and economic elite, whose interests were protected by a vast military apparatus that routinely brutalized the ethnic and religious minorities which it claimed to integrate into the peace of the Pax Romana. Raschke understands a cosmopolitan faux-humanitarianism undergirded by a vast military industrial complex as a feature of the post-WWII neoliberal world order in what we term the Euro-Christian West.

In finding the trace of these earlier disavowed state-forms in the logic and operation of neoliberal governmentality, Raschke challenges the ahistoricity in the official paradigms of the liberal democratic nation-state. His political theology takes a somewhat different approach than establishing a similitude between a particular political structure and the forms of an established religious tradition. These beliefs and practices, in understanding themselves to be secular, are also wholly immanent. This immanent piety somewhat complicates the dualistic structure common to most, but not all, political theologies. Indeed, Raschke also critiques projects of radical theology as simply articulations of a sacramentality of pure immanence. Through the attachment to the narrative of secularity, namely, a worldview which understands itself as having evolved beyond the need for religion and primitive superstition, the neoliberal cultural space paradoxically leaves the field wide open for the most powerful form of religiosity or ideology—the kind which does not recognize itself as such. Raschke details the moralisms, myths, and shibboleths of the contemporary neoliberal knowledge classes. These constitute the bourgeois piety of the neoliberal era, a values structure that holds up neoliberal systems of exploitation. In all of the fetishizing of productivity, efficiency, cosmopolitanism, and upward mobility, the pious neoliberal knowledge classes contribute the exploitation of both themselves and those who stand on lower rungs of the socio-economic ladder. The fantasy of upward mobility in fact effects a downward mobility both on economic and ecological registers.

If there is similitude to be found between neoliberalism's immanent religiosity and historically established religious forms, I argue that it is found in classical Roman religiosity. Political life in the Roman understanding had everything to do with religio—binding society back to the will of the gods, through the use of religious ritual, dogma, and tradition, as well as binding the society together through shared pietas. Marcus Terentius Varro's Antiquitates rerum humanarum et divinarum, which, in its full form, is unfortunately lost to history, articulated a threefold theology-theologia mythica, theologia civilis, and theologia naturalis. These are understood distinct fields of theology and religiosity that do not compete but harmonize with one another. In this, as well as in the understanding of thinkers such as Cicero, piety in Roman society was not exclusively a function of sincerity of belief regarding the gods. Fulfilling one's duty both to the gods and to society went rather beyond questions of sincerity or credulity. Neoliberal ideology lays claim to no singular religious tradition, rather, I argue that it is religious in the classical sense of ancient Roman religiosity. The structure of neoliberal piety involves implementing the mechanisms of Empire to bind citizens to an immanent frame. This piety involves a particular anthropology and structures human subjectivity implemented through technologies of both control (for example, by way of chronic indebtedness of neoliberal subjects) and devotion (Foucauldian voluntary "entrepreneurship of the self"). These structures of control and devotion, which are religious in the classical sense, leave plenty of room for individual alternative religious confessions and identities. Such identities are integrated into a streamlined, and of course, always 
profit-generating, hegemonic system. It follows something of the bargain of religious pluralism in ancient Rome, put rather baldly, You can worship any gods you'd like, just so long as you also serve ours.

Roger Green's 2019 (Green 2019) A Transatlantic Political Theology of Psychedelic Aesthetics: Enchanted Citizens constitutes quite a novel insight, insofar as it identifies a distinctly neoliberal religiosity in psychedelic culture and psychedelic aesthetics. Green reads aesthetics as an important site of political intervention and argues that "political theology has yet to engage seriously with the question of literary aesthetics" (Green 2019). His is a study of the political impact of the aesthetic sensibilities of psychedelia, which can be understood as an unexpected source of neoliberal piety. Psychedelic aesthetics both relates to and expands beyond the concrete use of psychedelic substances. During the 1960s in North America and Europe, a distinct culture developed around use of psychedelic substances. Various forms psychedelic or mind-altering substances have been used by indigenous and ancient cultures for millennia, but European and North American mass cultures experienced something of a rediscovery of such substances in the 1960s led by popular figures such as Terrence Mckenna and Timothy Leary. Green describes the preoccupation of Western psychedelic culture with the idea of a "re-enchantment" of society, constituting a kind of neo-mysticism unaware and uncritical of its historical and cultural "set and setting,".

Psychedelic culture and aesthetics are significant in their complication of the secular/religious binary. On the one hand, psychedelic culture fulfils almost all the criteria that traditionally mark a cultural form as "religion"; it involves speculative and sometimes esoteric metaphysical teachings and claims, ritualized ecstatic experiences in which participants often make claims of revelations from "beyond", and it has a devoted following which often expresses an evangelical impulse to share their insight or lifestyle with persons on the "outside" of the movement. On the other hand, those involved in psychedelic culture largely understand themselves as secular and often vehemently anti-institutional, especially when it comes to institutional religion. This psychedelic sub-culture left an indelible mark on the pop culture of the 1960s, a decade which remains today something of an aesthetic, cultural, and political flashpoint-a Golden Age of personal freedom, expressive individuality, and revolutionary potential, attractive for Leftists, liberals, the New Age movement, and the various countercultures that proliferated in the decades that followed. Green argues that psychedelia, both as sub-culture and broader aesthetic sensibility, is a mode of post-secular "enchantment", which, while posing as counterculture, functions as an important driver of the religious passion of the neoliberal status quo. He understands psychedelic aesthetics as the "mind-manifestation" of enchanted citizens; an aesthetics which expresses both neo-Romantic as well as neocolonial sensibilities in its naturalism, orientalism, and evangelical drive to universalism. Raschke also lends much attention to the continuing cultural currency of the 1960s in his Neoliberalism and Political Theology, who understands the neoliberal cultural sensibility as essentially libertarian, which is aestheticized through a combination of New Age aesthetics, an appropriation of some of the themes of justice and equality from the Civil Rights movement, and a cosmopolitan sensibility which inherits something from the modern colonialist sensibility. Green offers unique insight in his Transatlantic Political Theology of Psychedelic Aesthetics by detailing the far-reaching cultural and political significance in what many might consider a fringemovement, demonstrating in his political theological reflections that the best and most politically effective religion is that which does not recognize itself as such.

\section{Methodological Reflections}

\subsection{Normative-Prescriptive and Genealogical-Descriptive Political Theologies}

I would like to return to the methodological question, of what it precisely means to "do" political theology. This is the question of whether a purely descriptive approach is best suited to political theology, or if one can be said to "do" political theology in a normative, prescriptive, or confessional way. Most of the authors I have surveyed, with the exception of Carl Schmitt, have endeavored a descriptive political theology. I have 
handled political theology in the first order as a genealogical method which draws out the connection and mutual influence between theological paradigms and political theory. Political theology, insofar as it is genealogical, requires a historical sensibility, but it also relies on something of a Feuerbachian undecidability of interpretation in the theological realm. It rests on fundamental ambiguity of the question: who is the creator and who is the created? Or, put otherwise, do theological formulations simply reflect (1) the internal psychological make-up - the Ego-ideals, wishes, and fears of the human person? Or rather, are (2) theological formulations a reaction to some external force, divinity, or metaphysical order? Some would reduce this to either a credulous or atheistic reading of theology. For Feuerbach, however, these two theses blend into one another; even as he advocates for the first position, that theology or religion is only a projection of the internal landscape of the religionis animalis ${ }^{24}$, does this thesis itself not ultimately express or affirm something of a fundamental order of things? This paradox replicates itself in the dual, competing formulations of political theology from Carl Schmitt and Jan Assmann. Is every political concept a secularized theological concept as Schmitt says? Or rather, is every theological concept an elevated and absolutized political concept? Such a question is, in its way, unanswerable. In fact, the question should remain unanswered in order to preserve the illuminating potential of political theology as discipline. Furthermore, the preservation of this question protects political theology from devolving into two competing discourses, a theistic and an atheistic version.

Of course, there are many normative, confessional, or prescriptive projects which call themselves political theology. Carl Schmitt's political theology falls into this category. I would argue that an attempt to engage in political theology on a normative or prescriptive level presents a considerable methodological problem. The philosophical value of political theology as a discourse lies in its capacity to both (1) show the connections between theological and political discourses, their "cross-pollination", and (2) make visible their contingency. If it is true, as Eric Voegelin argues, that every political community constitutes a shared Cosmion, a shared set of cosmological, metaphysical, religious, or moral orientations (Voegelin 2004), what is philosophically interesting about this phenomenon is the plurality of constitution of these Cosmions. Each historic political community does not reproduce uniform microcosms of one static and unchanging metaphysical world order. Instead, the moral and metaphysical foundations of shared political life are demonstrated to be plastic, changeable, contingent. Therefore, to seek to mount a constructive or prescriptive theological or political position in political theology serves ultimately to obscure the very contingency which political theology has the potential to reveal. Ideally, in political theology, the analysis should be differentiable from the political or theological persuasions of the author, lest the connections between the constitution of the political and the theological and the view of their contingency be obscured. That is not to say that politics and theology should not be discussed in the same sphere, nor that one should not be allowed to mount a theological argument for a political position; it simply means that perhaps these projects should go by a name other than political theology.

There are at least two foreseeable objections to this methodological position. First would be the objection that the methodological approach put forward would render political theology an apolitical project. Second is that such a conception of political theology falls prey to the fallacy of the scholar as a neutral external observer to both religion and politics. To begin with the first objection: the temporary abstention from assuming a political position, to assume for at least a moment the view from the outside, illuminates the political field. This approach to political theology makes visible the political import of the history of theological contestations. To abstain, at least for a time, from confessional or identarian commitments, one gains a new perspective on their contingency. This view to contingency indeed has radical but subtle political import, namely, in the revelation that things could have been otherwise. If things could have been otherwise, then they might, with a view to the future, still become otherwise. This insight was at the core of Michel Foucault's intellectual project. One need not renounce forever her confessional, identarian, 
metaphysical, or ethical commitments to engage in political theology, but the simple willingness to bracket them for a time in order to recognize their historicity and contingency enables a transformed relationship with the future. With a view to neoliberalism, it lays bare the suffocating fallacy of Margaret Thatcher's famous mantra. It is simply not the case that "there is no alternative" to the neoliberal order. The political potential of such a position is hard to overstate.

The general consensus in contemporary humanities and social sciences is that the modernist understanding of the scholar as a neutral external observer is a dangerous fallacy. Instead, the researcher must locate her social, religious, racial, class, ideological and historical position while engaging in research and scholarly discourse. The zero point of neutral observation is a fallacy, but this understanding does not foreclose on the potential for rational analysis. Instead, it points to the opening of a broader philosophical question, with implications for our understanding of post-secularity. It could be said that, as a normative methodological principle, the scholar should locate herself while remaining be open to the likelihood of future dislocation. To further explore the implications of the fallacy of the neutral external observer, we will return to Jurgen Habermas and his understanding of the liberal democratic nation-state and post-secularity.

\subsection{Political Theology and Jürgen Habermas' Dialectic of Secularization}

In the Dialektik der Säkularisierung, Jürgen Habermas reflects that "In Tehran, a colleague asked me if it isn't true, from a cross-cultural perspective or from the perspective of sociology of religion, that European secularization is in fact the actual [historical] anomaly in need of correction. This reminds one of the cultural mood during the Weimar Republic, [it reminds one of] of Carl Schmitt, Martin Heidegger, or Leo Strauss" ${ }^{25}$. This question of how to interpret European-style secularity and its place in history is a difficult one, with profound political and philosophical implications. There are many admirable aspects to Habermas' philosophy of the constitutional state, for example, the consistent commitment to democratic and human rights principles. From a political perspective, it would not be the aim of this author to "correct" these aspects of Habermas' political theory. If Habermas' theory of state and secularity in general are in need of correction, it would be to correct the self-understanding of secularity as having transcended religion or religious concerns.

The contradictions inherent to this understanding of secularism play themselves out in Habermas' theorization of the liberal constitutional state in Dialektik der Säkularisierung. He understands the secular state as self-founding on the basis of practical reason. He promotes a "procedural constitutional state" inspired by Kant over and against a competing "Right Hegelian" theory of State (Ibid., p. 21). Here, we see him positioning his theory of state in dialogue with and diametrical opposition to Carl Schmitt's express position in his 1922 Political Theology. Habermas claims that that while the liberal constitutional State is founded and operates on a post-metaphysical, philosophical basis, metaphysical and religious understandings can be employed to promote solidarity amongst its citizens in a limited sense. While the state must limit itself to protecting the minimum rights, dignity, and responsibility of the individual person, religion can play a limited role in helping citizenry articulate understandings of "the good life" so long as these understandings play by a certain set of rules and norms set by the State (i.e., refraining from coercion in promoting their views and respecting the religious freedom of others). Finally, Habermas designates the political role of religious actors in a liberal constitutional state as "translators" of the more rigorously universal values set down by the State. The intention here is less to condemn or dispute Habermas' political position and much more to pose the question: How can this position be understood as anything other than a normative political theology?

The historical background of Habermas' state theory is significant. He is not only responding to the tradition of the Rechthegelianer or to Carl Schmitt but also the history of contestation between Church and State in Europe generally and to the political religious concerns in post-Reformation Germany more particularly. Habermas' is a theory of state in the shadow of the Treaty of Westphalia, an armistice ending the violent religious conflict 
of the Thirty-Year War. Westphalia initiated a long transition in Europe to a religiously neutral state form, which culminated in the liberal constitutional state and its guarantees of religious freedom of the individual. This final form, which Habermas promotes, was finally actualized in Germany in the 1919 Weimar Constitution. Germany is understood as having taken a "middle road" on the question of Church and State separation, thoroughly integrating the Lutheran Landeskirche and the Roman Catholic Church into the workings of the State, especially in the administration of social projects. ${ }^{26}$ The process begun at Westphalia can also be understood as a final answer to a long power struggle between religious and secular authorities in Europe-put baldly, the State as "earthly" authority won out over the ecclesial authorities in questions of political sovereignty.

We observe that Habermas takes the defense of Sovereign interests of the Constitutional State as his consistent point of departure. In articulating his view of the proper relation between State and Church, he even goes so far as to understand the State as able to dictate points of dogma for religions in matters where it has a vested interest. ${ }^{27}$ This is an odd position for an institution to take upon itself while also claiming to be in its very foundation post-dogmatic and post-metaphysical. The role of religion in the last instance, for Habermas, is the translation of the universal and rational values of the State into the religious vernacular of its non-secular citizens. The capacity for dogmatism amongst those who believe themselves to be beyond religion continues to impress.

In comparison with the previous survey of neoliberal political theology, there is something in Habermas' account which seems distinctly retro, something of an overestimation of the extent of the power of the State. However, similarly to our previous examples, Dialektik der Säkularisierung should be understood as a normative political theology. Theories of the secular liberal constitutional State, much like their predecessors, rely on metaphysical claims - claims about the nature, value, and purpose of humanity, claims about the good life, rituals of devotion or respect, deferral to authorities, etc. To have changed the nature of one's metaphysical claims is not the same as transcending the category of metaphysical claim. There is an essential continuity even between Habermas' theory of the political and preceding theories of the political that seem so radically divergent at first glance. For example, the Angelology of Thomas Aquinas and Dionysius the Aeropagite share an important feature with Habermas' theory of state: both take a claim about how the world, universe, or cosmos works and translates that view into a prescription of how the political world should function. Aquinas and Habermas share a similar credulity-that they have understood something of the essential order of existence and that that understanding informs how one should structure the political. It is in this sense that Enlightenment thought is not post-metaphysical and not post-religious even as the Enlightenment does indeed involve a radical transformation of the content of metaphysical claims. Through the disavowal of religion, the tradition of secular Enlightenment thought is able to operate at an even higher level of credulity regarding its own metaphysical claims.

\section{Conclusions}

Here, I have endeavored an account of what political theology has been, starting with the origins of the discourse in Carl Schmitt's 1922 work and followed by a close reading of Giorgio Agamben's genealogical account of the paradigms of governance and economy as they developed in Late Antiquity through the High Middle Ages and its implications for political theology. These accounts have provided historical examples and a methodological background for political theology, which can be defined as the discipline of drawing connections between religious and theological traditions and teachings and their mutual influence with the development of political theory. Of course, it is not just theory implicated in political theology, but also religious and political practices. Next, I turned to an account of more recent political theologies of neoliberalism. These rich and varied accounts consistently demonstrate the way in which political theology can function as a post-secular intervention. Movements that purport to be free of traditional religiosity or confession, for example, neoliberal economic theory or psychedelic subcultures prove to 
actually be rich sites of religiosity. Consistent to most of our examples is the intensification of the claims made in the realm of normative political theology when proponents do not understand themselves to be advancing a religious or metaphysical agenda. I closed with methodological considerations around political theology as a discipline and discourse, privileging a descriptive and genealogical political theology over a normative or confessional political theology. Political theology as a descriptive and genealogical discipline has the potential to reveal both the variety and contingency of normative political theologies as they have been deployed historically, and these insights are of both philosophical and political interest. Finally, I argue that Enlightenment discourses, such as the secularization thesis, misunderstand themselves as having transcended all religious and metaphysical concerns. Even as the nature of metaphysical claims have been transformed and inflected through the Enlightenment, and even as many of these inflections have proven positive, I critique the habit of secular thinkers of understanding themselves as beyond religiosity. Such claims have the paradoxical effect of heightening the dogmatic credulity that secular thinkers invest in their philosophical, metaphysical, and political claims.

Funding: This research received no external funding.

Institutional Review Board Statement: Not applicable.

Conflicts of Interest: The author declares no conflict of interest.

\section{Notes}

1 See Samuel Huntington (Huntington 1996), The Clash of Civilizations and the remaking of world order, London, 1996. Of course, Huntington's account is both dated and highly controversial, but it is cited here as a thesis that has set the parameters around common discussions around religion, politics, and globalization in both the scholarly discourse and the popular consciousness since its publication a quarter century ago. For rather more differentiated, nuanced, and recent studies on post-secularity and politics or "the return of religion", see Hent de Vries, Lawerence E. Sullivan (ed.) (de Vries and Sullivan 2006), Political Theologies: Public Religions in a Post-Secular World, New York City, 2006.

2 Early proponents of the secularization thesis include Karl Marx, Émile Durkheim, Max Weber, and others. Of course, secularization as a topic is complex; it can be spoken of on political, sociological, historical, and philosophical levels. Both defenses and 'post-secular' critiques of the secularization thesis can take place on all of these disciplinary registers. For a contemporary clarification of the secularization thesis by a self-proclaimed proponent, see, Steve Bruce, Secularization: In Defence of an Unfashionable Theory, Oxford, 2011. (Bruce 2011).

3 See Jürgen Habermas \& Joseph Ratzinger, Dialektik der Säkularisierung: Über Vernunft und Religion, 2005, Freiburg im Breisgau. into (Habermas and Ratzinger 2005).

4 For a succinct articulation of Assmann's approach to political theology, see Jan Assmann, Political Theology: Religion as legitimizing fiction in antique and early-modern critique originally published in Bernhard Giesen, Daniel Suber (Ed.), Religion and Politcs, Cultural Perspectives, Leiden \& London, 2005, pp. 193-203. (Assmann 2005).

5 Eric Voegelin, Die Neue Wissenschaft der Politik, 2004, Paderborn, p. 69. Translation my own: Alle frühen Reiche des Nahen sowie des Fernen Ostens faßten sich als Repräsentanten einer transzendenten Ordnung, der Ordnung des Kosmos auf ... Ob man sich den frühesten chinesischen Quellen im Shu-ching oder den ägyptischen, babylonischen, asszrischen, oder persischen Inschriften zuwendet, überall wird die Ordnung des Reiches als Repräsentation der kosmischen Ordnung in dem Medium der menschlichen Gesellschaft interpretiert. Das Reich ist ein kosmisches Analogen, ein Mikrokosmos als Spiegel des allumfassenden Makrokosmos. Herrschaft wird zur Aufgabe, die Gesellschaftsordnung in Einklang mit der kosmischen Ordnung zu bringen. (Voegelin 2004).

6 See Jacques Derrida, Force of Law: The Mystical Foundation of Authority in Acts of Religion, New York, 2002. Here, Derrida utilizes Schmitt's sovereign state of exception in his reading of Walter Bejamin's Kritik der Gewalt, originally given as two lectures in English between 1989 and 1990. The mystical foundation of authority is both a reflection on the history the extra-legal foundation of law in some mystical, external moment of decision as well as the irreducibility of justice to questions of law; put otherwise, the aporetic irreconcilability of law and justice. (Derrida 2002).

7 The use of male pronouns is intentional here. The question a female Sovereign was never officially raised with Schmitt, but one could be relatively certain the idea would be dismissed as briskly as the idea of using "She" as a pronoun for the Christian God. There is a gendered dimension to sovereign decisionism in particular and political theology as a discipline that is certainly worthy of attention, but the parameters of this piece are too narrow to do the topic justice.

8 For more detail, see Paul Noack, Carl Schmitt: Eine Biographie, Wien, 1993. This is but one of multiple high-quality biographies of Schmitt which handle in detail his involvement with the NSDAP and the significance of his thought for the Third Reich, as well 
as the significance of his involvement in Nazi Party for his political thought. Politische Theologie II, published 1970, is understood to be, in part, an attempt by Schmitt to vindicate his political theory in light of his Nazi involvement. (Noack 1993).

9 Euthyphro, 10a.

10 In many instances, I am choosing to make use of the moniker "eurochristian" put forth by Roger Green and Tink Tinker in place of "Western" or "European" insofar as it is a superior shorthand descriptor in terms its accuracy and succinctness to describe the matrix of European Christian influenced political history and history of ideas.

11 See, for example, another paradigmatic study in political theology from the mid-20th century, first published in 1957, Ernst H. Kantorowicz, The King's Two Bodies: a study in medieval political theology, Princeton, 2016. (Kantorowicz 2016).

See, for example, the recent, Stefahn Schwarzkopf (ed.), The Routledge Handbook of Economic Theology, New York, 2020. (Schwarzkopf 2020).

Agamben's argument has its critics. One of the most recent and thorough critiques is Dotam Lesham, The Origins of Neoliberalism: Modeling the economy from Jesus to Foucault, New York, 2016. Still, the Kingdom and the Glory remains a strong elaborations of political theology and provides a theoretical framework for economic theology. For that reason, it retains a prominent place in this study, as a necessary text for understanding 21st century works in economic theology. (Lesham 2016).

Elisabeth Schüsser Fiorenza develops the neologism kyriarchy (from the Greek Kyrios or Lord) as an alternative descriptor of this political heritage and inheritance, considering it more accurate than the more common patriarchy. We find here again intimations of the politics of gendered exclusion found throughout the Euro-Christian history of political thought, a masculinist pre-occupation which I would argue extends to political theology as a discourse. Fiorenza includes some preliminary observations in the direction of a feminist reading of political theology. See Political Theology: Contemporary Challenges and Future Directions, Louisville, 2013, pp. 23-35. (Schüsser Fiorenza 2013).

For a much more detailed handling of this development, see Agamben's The Kingdom and the Glorypg. pp. 17-52. (Agamben 2011).

18 There is a rich medieval tradition of using the hunt, especially falconry, as a metaphor for governance. See especially the treatise De Arte Venandi cum Avibus written by Emperor Friedrich II von Hohenstaufen in the 1240s, which influenced attitudes about the analogy between governance and the hunt well into the 18th century.

19 The discussion currently centers on the Christian Trinitarian God, but the structure of the observation holds for the other Abrahamic religions as well as some monotheistic non-Abrahamic religions, for example, in the case of Akhnaten in ancient Egypt, as established by Jan Assmann in both From Akhenaten to Moses: Ancient Egypt and Religious Change, Cairo, 2016, as well as in Politische Theologie zwischen Ägypten und Israel. Munich, 2006. (Assmann 2006). See Slavoj Žižek, The Parallax View, Cambridge, 2006. (Žižek 2006).

Scholars have theorized since the end of the 19th century that the Pseudo-Dionysius may have been a student of Proclus and was most definitely a contemporary familiar with his works. See: Corrigan, Kevin and L. Michael Harrington, "PseudoDionysius the Areopagite", The Stanford Encyclopedia of Philosophy (Winter 2019 Edition), Edward N. Zalta (ed.), Available online: https:/ / plato.stanford.edu/archives/win2019/entries/pseudo-dionysius-areopagite (accessed on 24 August 2021). See Paul Rorem, The Dionysian Mystical Theology, Minneapolis, 2015. (Rorem 2015).

23 Examples of which include Adam Kostko, Neoliberalism's Demons: On the political theology of late capital, Stanford, 2018 (Kostko 2018); Catherine Keller, Political theology of the earth: Our planetary emergence and the struggle for a new public, New York, 2018 (Keller 2018); Karen Bray, Grave Attending: A political theology for the unredeemed, New York, 2020 (Bray 2020); and Devin Singh (Singh 2018), Divine Currency: The theological power of money in the west, as well as previous projects from Carl Raschke such as Force of God: Political theology and the crisis of liberal democracy and later projects from Philip Goodchild's later series on Credit and Faith, see Philip Goodchild Credit and Faith, Lahnam, 2019 (Raschke 2015) (Goodchild 2019); Philip Goodchild, Economic Theology: Credit and Faith II, Lahnam 2020; Philip Goodchild (Goodchild 2020) The Metaphysics of Trust: Credit and Faith III, Lahnam, 2021 (Goodchild 2021). These works represent diverse approaches to political theology and indeed I find some significant weaknesses in some of the more normative-prescriptive approaches inasmuch as some of them fail to sufficiently contextualize themselves methodologically. Furthermore, some of these works are more focused on neoliberalism as it functions in the contemporary world while others are much more focused on historical geneologies. Recent relevant anthologies in political theology and economic theology have been cited elsewhere in this work.

24 See Ludwig Feuerbach's discussion of religionis animalis in his Introduction "Das Wesen des Menschen im allgemeinen" in Das Wesen der Christentum, Leipzig. (Feuerbach 2014).

25 Jürgen Habermas, Joseph Ratzinger, Dialektik der Säkulasierung: Über Vernunft und Religion, Freiburg, 2005 p. 28. Translation my own, „In Teheran fragte mich ein Kollege, ob nicht aus kulturvergleichender und religionssoziologischer Sicht die europäische Säkularisierung der eigentliche Sonderweg sei, der einer Korrektur bedürfe. Das errinert an die Stimmungslage der Weimarer Republic, an Carl Schmitt, Martin Heidegger oder Leo Strauß." (Habermas and Ratzinger 2005).

26 For a short introductory overview of the tradition which so influences Habermas' thought on this issue, see Gerhard Robbers, State and Church in the European Union, Baden-Baden, 1995, pp. 77-94. (Robbers 1995). 
See again Jürgen Habermas, Joseph Ratzinger, Dialektik der Säkulasierung: Über Vernunft und Religion, Freiburg, 2005, pp. 32-35. Some of that extraordinary claim for the State to influence religious teaching is reproduced here for reference, "So liegt es auch im eigenen Interesse des Verfassungsstaates, mit allen den kulturellen Quellen schonend umzugehen, aus denen sich das Normbewusstsein und die Solidarität von Bürgern speist. ... Der Ausdrück "postsäkular" zollt den Religionsgemeinschaften auch nicht nur öffentliche Annerkennung für den funktionalen Beitrag, den sie für die Reproduktion erwünschter Motive und Einstellungen leisten. To solidify the point, Habermas clarifies a few pages later, Und da der liberale Staat auf eine politische Integration der Bürger, die über einen bloßen modus vivendi hinausgeht, angewiesen ist, darf sich diese Differenzierung der Mitgliedschaften nicht in einer kognitive anspruchslosen Anpassung des religiösen Ethos an auferlegte Gesetze der säkularen gesellschaft erschöpfen. Vielmehr müssen die universalistische Rechtsordnung und die egalitäre Gesellschaftsmoral von innen her so an das Gemeindeethos angeschlossen werden, dass eins aus dem anderen konsistent hervorgeht ... Die normative Erwartung, mit der der liberale Staat die religiösen Gemiende konfrontiert, trifft sich mit deren eignen Interessen insofern, als sich diesen damit die Möglichkeit eröffnet, über die politische Öffentlichkeit einen eignen Einfluss auf die Gesellschaft im Ganzen auszuüben. (Habermas and Ratzinger 2005).

\section{References}

Agamben, Giorgio. 2011. The Kingdom and the Glory: For a Theological Genealogy of Economy and Government. Stanford: Stanford University Press.

Assmann, Jan. 2006. Politische Theologie zwischen Ägypten und Israel. Munich: Siemens Stiftung.

Assmann, Jan. 2005. Political Theology: Religion as legitimizing fiction in antique and early modern critique. In Religion and Politics, Cultural Perspectives. Edited by Bernhard Giesen. Leiden and London: Brill Academic Publishing, pp. 193-203.

Böckenförde, Ernst-Wolfgang. 1991. State, Society and Liberty. Studies in Political Theory and Constitutional Law. New York: Berg Publishers.

Bray, Karen. 2020. Grave Attending: A Political Theology for the Unredeemed. New York: Fordham University Press.

Bruce, Steve. 2011. Secularization: In Defense of an Unfashionable Theory. Oxford: Oxford University Press.

Derrida, Jacques. 2002. Force of Law: The Mystical Foundation of Authority in Acts of Religion. New York: Routledge.

de Vries, Hent, and Lawerence E. Sullivan, eds. 2006. Political Theologies: Public Religions in a Post-Secular World. New York: Fordham University Press.

Feuerbach, Ludwig. 2014. Das Wesen des Christentums. Köln: Anaconda Verlag.

Goodchild, Philip. 2009. Theology of Money. Durham and London: Duke University Press.

Goodchild, Philip. 2019. Credit and Faith. Lahnam: Rowman \& Littlefield Publishers.

Goodchild, Philip. 2020. Economic Theology: Credit and Faith II. Lahnam: Rowman \& Littlefield Publishers.

Goodchild, Philip. 2021. The Metaphysics of Trust: Credit and Faith III. Lahnam: Rowman \& Littlefield Publishers.

Green, Roger K. 2019. A Transatlantic Political Theology of Psychedelic Aesthetics: Enchanted Citizens. London: Palgrave.

Habermas, Jürgen, and Joseph Ratzinger. 2005. Dialketik der Säkularisierung: Über Vernunft und Religion. Freiburg im Breisgau: Herder. Huntington, Samuel. 1996. The Clash of Civilizations and the Remaking of World Order. London: Simon \& Schuster.

Kantorowicz, Ernst H. 2016. The Kings Two Bodies: A Study in Medieval Political Theology. Princeton: Princeton Classics.

Keller, Catherine. 2018. Political Theology of the Earth: Our Planetary Emergence and the Struggle for a New Public. New York City: Columbia University Press.

Kostko, Adam. 2018. Neoliberalisms Demons: On the Political Theology of Late Capital. Stanford: Stanford University Press.

Lesham, Dotan. 2016. The Origins of Neoliberalism: Modeling the Economy from Jesus to Foucault. New York: Columbia Univeristy Press.

Noack, Paul. 1993. Carl Schmitt: Eine Biographie. Wien: Propyläen Verlag.

Ramey, Joshua. 2016. Politics of Divination: Neoliberal Endgame and the Religion of Contingency. London and New York: Rowman \& Littlefield.

Raschke, Carl A. 2015. Force of God: Political Theology and the Crisis of Liberal Democracy. New York: Columbia University Presss.

Raschke, Carl A. 2019. Neoliberalism and Political Theology: From Kant to Identity Politics. Edinburgh: Edinburgh University Press.

Robbers, Gerhard, ed. 1995. State and Church in the European Union, 3rd ed. Baden-Baden: Nomos.

Rorem, Paul. 2015. The Dionysian Mystical Theology. Minneapolis: Fortress Press.

Schmitt, Carl. 2015. Politische Theologie: Vier Kapitel zur Lehre von der Souveränität-Zehnte Auflage. Berlin: Dunker \& Humblot Verlag.

Schwarzkopf, Stefan, ed. 2020. The Routledge Handbook of Economic Theology. Milton Park: Routledge.

Schüsser Fiorenza, Elisabeth. 2013. Critical Feminist The*logy of Liberation: A Decolonizing Political The*logy. In Political Theology: Contemporary Challenges and Future Directions. Edited by Michael Welker, Francis Schüssler Fiorenza and Klaus Tanner. Louisville: Westminister John Knox Press, pp. 23-35.

Singh, Devin. 2018. Divine Currency: The Theological Power of Money in the West. Stanford: Stanford University Press.

Voegelin, Eric. 2004. Die Neue Wissenschaft der Politik: Eine Einführung. Paderborn: Wilhelm Fink Verlag.

Žižek, Slavoj. 2006. The Parallax View. Cambridge: The MIT Press. 